\title{
Assessment of Indoor Air Quality in Buildings using CFD: A Brief Review
}

\author{
Venu Shree \\ Department of Architecture \\ National Institute of Technology Hamirpur, 177005, Himachal Pradesh, India \\ Corresponding author: venushree80@gmail.com \\ Bhanu M. Marwaha \\ Department of Architecture \\ National Institute of Technology Hamirpur, 177005, Himachal Pradesh, India \\ Pamita Awasthi \\ Department of Chemistry \\ National Institute of Technology Hamirpur, 177005, Himachal Pradesh, India
}

(Received January 15, 2019; Accepted June 1, 2019)

\begin{abstract}
The building provides shelter to live and most people spend their $85-90 \%$ time indoors. Therefore, it is quite important to ensure that the condition of the indoor environment is healthy for its living being. There are a number of methods to evaluate indoor air pollution of built spaces by performing experiments or doing it computationally. In this study, a review of computational studies carried out to evaluate the impact of different parameters like airflow pattern, indoor and outdoor contaminant concentrations etc., on indoor air quality (IAQ) of different type of buildings was done. Some commonly used software's for the study of IAQ were also discussed.
\end{abstract}

Keywords- Indoor air, Computation, Building, CFD.

\section{Introduction}

Actually, cooling or heating of a built space to maintain indoor thermal comfort is a major source that accounts for around 60-70\% of building energy consumption. Nowadays, the building sector alone is accounted for nearly $40 \%$ of annual energy consumption (world). At present, around 31 cities worldwide are having a population of more than 10 million (United Nations, 2016) and many of them are located in developing and poor countries and they are characterized by enhanced pollution levels (air). Buildings should provide a good indoor environment, which allows occupants to do various activities (Wang et al., 2017). However, continuous effort in reducing building energy consumption is required due to the depletion of fossil energy resources along with the effect of global warming (Hong et al., 2017). Good IAQ with less energy usage is the main objective of building users and designers. Energy usage and comfort levels are highly dependent on incoming fresh air. Architects and designers had started making building more air tight in order to minimize the heating and cooling load requirements. This reduced ventilation rate leads to indoor air pollution. Natural ventilation helps to improve IAQ through dilution of indoor air pollutants. The study of Indoor Air Pollution (IAP) has emerged into a new discipline which requires knowledge in many areas. It deals with the principle of species concentration, fluid mechanics, heat transfer etc. 
International Journal of Mathematical, Engineering and Management Sciences

Vol. 4, No. 5, 1154-1168, 2019

https://dx.doi.org/10.33889/IJMEMS.2019.4.5-091

Computational Fluid Dynamics (CFD) was not initially developed for modelling buildings. However, development leads to its application in various areas i.e. heat transfer, combustion equipment, design of various turbo-machines, biological flows etc. (Nautiyal et al., 2010; Kumar and Kumar, 2017, Banerjee et al., 2017; Kumar et al, 2019). Its basic philosophy is to numerically solve physical process by set of governing equations. These governing equations show fundamental laws i.e., conservation of momentum, mass, energy and species concentration. It was used for prediction of air movement in a built space since the seventies and now efforts were made to use CFD as a reliable tool for the estimation of (IAQ) Indoor air quality. One of the earlier studies on numerical simulation of air flow in rooms was carried out using stream-vorticity approach by Nielsen (1974). Magnussen and Hjertager (1977) had used finite volume approach to solve 3-D primitive motion equation. Recent studies on air pollutants exposure to human beings signify that indoor levels of air pollutants may be 2-5 times, and sometimes even higher than this as compared with the outdoor levels. These concentration levels of pollutants are of prime concern because most of the people spend about their $90 \%$ of time indoors (Teodosiu et al., 2014). In assessing thermal comfort and IAQ, the air movement inside the built space is quite important. The flow comprises of velocity, species concentration, relative humidity, temperature and air flow pattern. The air flow pattern inside a room depends upon various factors i.e., size and position of window/door, the position of exhaust, availability of energy source etc. to estimate the indoor airflow for the built environment, models were made in accordance with the size of the building (full scale or small scale). The execution of such experiments are used to be very expensive and time consuming, therefore CFD is used as an alternative method to study the impact of different variables on the IAQ and thermal comfort.

\subsection{Objective of Study}

The objective of this study is to discuss the contribution of computational methods for the understanding of IAQ. This article discusses the impact of design and parametric studies conducted on various indoor environments. The applicability of software used for the estimation of IAQ is also discussed.

\section{Computational Techniques}

Simulations give rise to better, cheaper and quicker design processes and it can facilitate society aspirations for sustainable development. In this section, computations methods used for building simulations especially for indoor air quality are discussed.

\subsection{Building Simulation}

The unique building not only has better heating, air conditioning, ventilation system and envelope components (windows, roof and walls), but also has better inclusive execution as an integrated system. The commercial building has dynamic and complex interactions between its system and environment. This complex interaction needs to be simulated and modelled. Building simulation is the technique that has been used by engineers and architects (Hong et al., 2000). Engineers and architects were mainly dependent upon manual interpretations and calculations using designated design guidelines and also use rule-of thumb method before using the computer for building simulation (Clarke, 2001). Energy-efficient designs for large and complex building structure are difficult to predict without the computer-aided building performance simulations (BPS). Now, computer aided BPS access on the personal computer of engineers and architects provide facilities to develop new energy efficient building designs prior to construction of the building. These BPSs is promoting energy saving through better design of complex buildings. 
International Journal of Mathematical, Engineering and Management Sciences

Vol. 4, No. 5, 1154-1168, 2019

https://dx.doi.org/10.33889/IJMEMS.2019.4.5-091

Clarke and Hensen (2015) had investigated the BPS contribution in stimulating with the fabrication of an energy efficient environment. They distinguished the program that is using for BPS and contributed in this field nowadays. They questioned on the use of the simulation methods that integrated BPS platform having the capability or not to characterize the real-world complexity that supports user understanding. They had also stated that only time will tell, that the use of over simplified techniques or methods for BPS continues to be shoved onto unsuspecting users.

\subsection{CFD}

Navier-Stokes (N-S) equations are derived by applying the principles of conservation of momentum and mass to a control volume of fluid along with energy and species concentration. The analytical solution is not possible hence numerical techniques are used for the solution. For this purpose, discretization is required using finite difference, finite element, finite volume method (FVM) etc. The studied volume is divided into a high number of smaller cells which is known as the grid. The selection of grid is quite important as the solution accuracy, speed and convergence depend upon this. The air inside a building is having low velocity and high turbulence and it is considered to be incompressible.

\subsection{Lattice Boltzmann Method}

The lattice Boltzmann (LB) method has shown importance in simulating the air-flows with complex physics (Chen and Doolen, 1998; Succi, 2001). Numerical methods conventionally solve the N-S equations. However, the LB method is based upon the Boltzmann eq ${ }^{\mathrm{n}}$ with discrete velocity fields (Qian et al., 1992). LB method has an advantage of less computational time and effort. LB method is based upon the equation of the state; hence Poisson equation solution which costs significant computational efforts is not necessary like conventional CFD methods (Stratford and Pagonabarraga, 2008). It is also capable in assessing the arbitrary curved boundary and efficient in case of turbulent flows. It has also applicability in IAQ, but its use in this field is not explored fully yet. There are few studies available in the literature with the applicability of this method in IAQ. Jafari et al. (2010) had used this model in a 2D channel flow to assess the particle deposition and dispersion over a square cylinder.

Ding and Lai (2013) have used the 3-D multiple-relaxation-time (MRT) LB and Lagrangian particle tracking methods. They took the ventilated room with a partition to simulate particle dispersion and turbulence airflow. This method with the Smagorinsky model was used to simulate the turbulent airflow. They verified numerical results with experimental results and found a good agreement between the data. Results revealed that MRT-LB method provides better results for airflow than standard and RNG $\mathrm{k}-\varepsilon$ models. Multi-block grid refinement technique was employed to ameliorate the efficacy of the MRT-LB method. They considered the particle of size from 1 to $10 \mathrm{~mm}$ in diameter for the investigation of particle dispersion in the selected room. They found out that dispersion characteristics of particles were successfully assessed with this model. Sajjadi et al. (2016) had investigated the turbulent indoor airflow with hybrid, LENS and hybrid LES/RANS turbulence models within the frame work of the LB method. They used the Smagorinsky model to study sub-grid scale turbulence efforts. Results revealed a good agreement with experimental data. They found this model was less accurate than LES and more accurate than RANS. The computational time for the present model was less than LES but higher than RANS. Khan et al. (2015) had investigated the temperature and airflow inside a $32 \mathrm{~m}^{3}$ test space. The result shows that the LB method is faster than the LES in terms of computation time. They also stated that LBM based method which was used by the authors would be accelerating the 
International Journal of Mathematical, Engineering and Management Sciences

Vol. 4, No. 5, 1154-1168, 2019

https://dx.doi.org/10.33889/IJMEMS.2019.4.5-091

optimization process of building ventilation system for the period of the design phase, and also permitting real-time control and estimate for building management systems. Not much work reported on IAQ using LBM might be complexity involved in the 3D domain.

\subsection{Coupling Approach}

In coupling approach, two different approaches are used and combine together to take the advantage of these approaches. For example, multi-zone method is coupled with computational fluid dynamics (CFD). For the coupling of multi-zone and CFD together in the case where inlet momentum changes flow locally but mainly airflow pattern is not affected for CFD zone, the pressure boundary condition is applicable (Negrao, 1995). Bartak et al. (2002) had described the results of a research project sponsored by the EU commission. They used the method for integrating the low and thermal domains with the help of CFD model and conflation controller was used to ameliorate the simulation results for each time step and to ensure that this model was suitable for the given conditions. The CFD module of the ESP-r integrated modelling package (open source) has used for surface heat transfer, ventilation openings, treatment of complex geometries, blockages, buoyancy and the evaluation of the temporal and spatial deviation of thermal comfort and IAQ. They had found out that this module has the capability to provide better information about IAQ. Mu et al. (2015) had studied the volatile organic compounds (VOCs) emission process from building material. They used Langmuir isotherm sink model first time for this model. This model has employed with adsorption/desorption process effect between absorbed VOCs on material surfaces and gas phase VOCs in pores. Random generation-growth algorithm for 3D microstructures fibers was used for the porous material adoption for the present employed model. This model is used along with the LB method to assess the FVM for macroscopic transport and pore-scale diffusion. The authors validated the model by diffusion model (well mixed). They had investigated the impacts of Reynolds number, partition coefficient, and adsorption/desorption rate constants and Schmidt number on VOCs desorption/adsorption process in material (building). Results revealed that the model provided a good agreement for numerical estimation of VOCs concentration. They found out that VOCs concentration reduced with adsorption constant and enhanced with desorption rate constant. Partial coefficient and VOCs concentration are inversely proportional to each other. The alteration in pores of material affected the Schmidt number. This number had no effects on VOCs concentration in the chamber. Higher Reynolds number helps in attained equilibrium state earlier.

The simulation tools used for building simulation are not able to assess the detailed information in less time. These tools are not much efficient in case of emergency management. Multi-zone airflow network models have less computing time but have limitations in providing detailed information of contaminant transport and flow inside the buildings. However, CFD is capable in detailed assessment of various factors inside the buildings. But it requires a very long time. Wang and Emmerich (2010) had investigated the effect of portable generator on $\mathrm{CO}$ emissions near by the house or in the house with the help of CONTAM IAQ model coupled with CFD software. They discussed the effect of generator location, direction of tailpipe emissions and size of window opening towards the generator. They also studied the impact of uncontrollable factors (house dimensions, wind and temperature). The result shows that the direction of winds perpendicular to the open window led to more $\mathrm{CO}$ infiltration as compared to other angular direction of winds. The speed of wind had also affected the concentration of $\mathrm{CO}$ inside the room. They found out more $\mathrm{CO}$ infiltration at low speed of the wind when temperature difference in outdoor and indoor environment is small (buoyancy effect is lower). CO concentration was assessed with the combined effect of buoyancy and wind, if the buoyancy effect is considerable. 
International Journal of Mathematical, Engineering and Management Sciences

Vol. 4, No. 5, 1154-1168, 2019

https://dx.doi.org/10.33889/IJMEMS.2019.4.5-091

Wang and Chen (2008) had assessed the contamination with the help of coupled multi-zone-CFD model in less computing time. A three story, naturally ventilated building (with large atrium) was chosen for the study. Authors studied air-flow and contaminant dispersion in this building. This study also discussed the effectiveness of the building using emergency ventilation. They found out good results which provide detailed information about contaminant dispersion in less time. The facts studied were helpful in placement of contaminant sensors and govern evacuation strategies in an emergency. They also found out that multi-zone-CFD program are beneficial and efficient in the problems which require much computing time and multiple test runs. On the other hand, Srebric et al. (2008) had indicated that the multi-zone models provided similar or slightly better results than the coupled model for all the zones instead of contaminant distribution zone. They found less computing time with multi-zone alone as compared to coupled CFD-multi-zone model, but higher than CFD alone. Co-simulation allows various models to be simulated by various simulation programs running simultaneously and exchange data depending upon state variables (Dols et al., 2016).

\section{CFD Studies in Built Environment}

Computational fluid dynamics (CFD) is useful for the simulation in the estimation of indoor air pollution. Few studies were presented for different types of building to see the applicability of CFD in IAQ.

\subsection{IAQ in Kitchen}

In the kitchen, a high number of pollutants were formed due to various cooking activities and subsequently released into the air which affects the indoor air quality (IAQ). CFD has become an important powerful tool applied for predicting indoor airflow fields, pollutant transportation, temperature distribution etc. (Fletcher et al., 2001; Zhai and Chen, 2005). Some CFD studies relevant to the kitchen are discussed in this section.

Chiang et al. (2000) has carried out numerical study using the finite volume method (FVM) method on IAQ of residential kitchens in Taiwan. The study investigates the temperature, flow and carbon monoxide distribution in the kitchen. The result shows that accumulation of air contaminants is relevant at the location of gas and providing hood is good in eliminating contaminated air. Zhou and Kim (2011) has studied IAQ of kitchen and living room of Korean apartment. The effect of extraction flow rate $\left(0-1000 \mathrm{~m}^{3} / \mathrm{h}\right)$ and the angle between inlet air flow and ceiling (90, 45 and 22.5) on temperature, flow field and $\mathrm{CO}_{2}$ concentration has been investigated using Fluent 6.3. The result shows that at the beginning of cooking process temperature increases sharply and also the same trend is observed for the $\mathrm{CO}_{2}$ concentration. To minimize energy consumption the hood during cooking is operated at high flow rate while after cooking it operates at low flow rate. Lim and Lee (2008) has studied the flow characteristics of hood systems using 3D numerical analysis method to expel pollutants more efficiently using Fluent. The study focuses on the temperature, velocity, concentration field variation depending upon with or without separation plate and also on the shape of the plate. Result also shows that no separation plate model is more efficient in terms of temperature and $\mathrm{CO}_{2}$ distribution as compared to other models. Lai and Ho (2008) has numerically simulated particle simulation in a kitchen using Fluent 6.1. These result matches reasonably well with the experimental results. It also shows concentration at the near-field is almost three times as high as that at the far-field. Ruth et al. (2013) has studied the global health impact of poor IAQ by using biomass as fuel. The study comprises of survey, physical model (experimental study) and a computational model using CONTAM. Result shows that ventilation improves the quality of air indoors. 
International Journal of Mathematical, Engineering and Management Sciences

Vol. 4, No. 5, 1154-1168, 2019

https://dx.doi.org/10.33889/IJMEMS.2019.4.5-091

\subsection{IAQ in Educational Buildings}

Ventilation in school building seems to be a typical issue in many countries. During school building renovation process, dealing with IAQ is especially a challenging issue. Educational buildings rooms such as conference halls, classrooms, auditoriums, etc. are having a higher density of occupants i.e. approximately one person with in $2 \mathrm{~m}^{2}$ of floor area (Jurelionis and Seduikyte, 2008). Therefore, the installation of HVAC systems for better IAQ demands comparatively high maintenance costs and investment. Hence, the IAQ vitiates in the educational building due to improper HVAC systems. The influence of the indoor pollutants on the inhabitants depends on their physical condition and age. In addition, children are commonly more exposed to air contaminants as compared to adults (Wang et al., 2017). The adverse effects of the poor IAQ in educational buildings lead to the health problem of children. Higher $\mathrm{CO}_{2}$ concentration and sick building syndrome (SBS) were fixed for metering IAQ. Results revealed that $\mathrm{CO}_{2}$ concentration was found to be higher as compared to the limit despite of country (Limb, 1997). And the problem associated with the building due to poor IAQ can reduce the productivity of children. Although, better ventilation can leads to better performance of the children at school. After the long term, poor IAQ can cause severe diseases i.e. asthma and allergic diseases. Jurelionis and Seduikyte (2008) has studied the IAQ in two schools of Lithuania. They found out poor IAQ as $\mathrm{CO}_{2}$ concentration was higher in most of the experiments. When air supply inlets were installed, field assessment exhibited higher air velocity near the windows due to the lesser window surface temperature. They did simulation with CFD to study the cause of air dropdown in classrooms, CFD software was used. They had studied numerous air distribution schemes and ventilation systems were for simulation. They suggested some constructional consideration for better IAQ and to evade down draughts from cold windows.

Song and Meng (2015) had investigated the ventilation of one classroom in China with Fluent CFD software. The investigation was executed to gather the boundary conditions data for CFD simulation. They investigated four types of ventilation systems and compared their performance. Results revealed that double row windows were able to provide better thermal comfort conditions inside the classrooms. They had also found out that ceiling fans can ameliorate the occupied zones environment. A survey was also conducted through questionnaire for three weeks. They found out a very good agreement in simulation and investigation results through questionnaire. The student had problem of chest stuffiness who were residing in the poor ventilation zone. However, the student could more concentrate on their studies that were in the good ventilation zone. These results were all confirmed by the simulation.

\subsection{IAQ in Different Type of Buildings}

Abanto et al. (2004) had carried out numerical simulation for the estimation of comfort properties in a research centre room. The parameters studied were relative humidity, air velocity and air temperature. In order to study the impacts of occupant presence, two models were created. In the first model there are no occupants while in the second model three persons were considered. For the better visualization, five-inlet sections were created. Heat generation values were selected based upon the equipment availability in the room. Fluent software was used to carry out simulations and calculations had been done to estimate the mean age of air (MAA), predicted the percentage of predicted (PPD), dissatisfied mean vote (PMV) and mean radiant temperature (MRT).

Tian et al. (2006) had carried out CFD simulation of a room by using Fluent software. The three turbulence models were used for the validation of experimental results and the result shows that 
International Journal of Mathematical, Engineering and Management Sciences

Vol. 4, No. 5, 1154-1168, 2019

https://dx.doi.org/10.33889/IJMEMS.2019.4.5-091

RNG based LES model shows the best results. However, still there is a need to use another variant of LES for the assessment of IAQ. Hong et al. (2017) had carried out a study in classrooms of an educational facility in Seoul, Korea. In this case, energy consumption and temperature distribution were studied by keeping classroom windows fully opened as per natural ventilation. The simulations were conducted as per the actual schedule of school. These results were achieved by using CFD simulation. The school (elementary) classrooms located in the South Korean city of Seoul, was chosen as a case for the study. The sliding windows were installed on the wall to utilize natural ventilation during the summer season. For the simulation, weather data is taken from Incheon and indoor temperature was kept fixed to $25^{\circ} \mathrm{C}$. For the analysis of building standard k- $\varepsilon$ model was chosen as the turbulence model and Star-CCM software was used. Three scenarios were studied i.e., without ventilation, ventilation (natural) through windows for 30 and 50 minutes in each hour. The result shows that natural ventilation is able to meet all indoor thermal comfort of occupants and energy saving.

Gan (1995) has carried out numerical investigation of air movement, thermal comfort, contaminant dispersion and energy utilization in a mechanically ventilated office for a variety of air supply and extraction arrangements. In total 13 simulations were performed for UK summer cooling and winter heating conditions. Zhuang et al. (2014) has investigated formaldehyde distribution in an office room under 12 different arrangement of ventilation scheme and furniture layout. CFD simulations were carried out for all 12 cases using commercially available software CFX (Ansys 13). Shah and Dufva (2017) has studied the $\mathrm{CO}_{2}$ distribution around the room at Mikkeli (Finland). Comparison between the results obtained from CFD and experimental shows that computer simulation is having great potential in the study of air flow.

\section{Software Used}

A lot of commercial and open source software's are available for building simulation. Some of them are based on Building simulation tools and some are based upon computational fluid dynamics. Now few software's are available on the coupling approach in which for both the simulation methodology (Building simulation and CFD) were adopted. In this section few software were discussed used in the analysis of IAQ.

CONTAM is a multi-zone IAQ and ventilation study software developed by the Building and Fire Research Laboratory (NIST, 2005). It is used to simulate different flows, the concentration of contaminant etc. It is based upon the coupling approach. Barbosa and Brum (2018) had discussed the application of CFD-0 software in hospitals and laboratories for the simulation of airborne contaminant transport. For displacement and mixed ventilation, they found out the satisfactory performance of contaminant transport by room indoor airflow simulation using CFD0 . The estimated outcome with calculations on ventilation performance and personnel exposure to hazardous substances in hospital and laboratories are more significant than using the "perfect mixing" assumption. Wang and Chen (2007a) has assessed the use of external CFD link for an understanding of the effect impact of contaminant concentrations and wind pressure coefficients at the building surface. They studied a computer program that transforms coefficients of wind pressure to the required format for CONTAM. Results demonstrated that the prediction of the air infiltration and wind coefficient has been better estimated with this external link. In addition, the entrenched CFD zone is very advantageous for the investigation of contaminant transport. They had finally concluded that this feature of external CFD link gives a better estimation of IAQ analysis and design of the ventilation system. 
International Journal of Mathematical, Engineering and Management Sciences

Vol. 4, No. 5, 1154-1168, 2019

https://dx.doi.org/10.33889/IJMEMS.2019.4.5-091

Contaminant concentrations, air momentum effects and air temperatures are assumed to be homogeneously and uniformly dispersed for current multi-zone airflow network models. But, the distribution is not uniform in some areas and these assumptions can cause errors. A coupled CFD and multi-zone program has been used to model the poorly mixed zones to avoid the errors and more impactful results. Wang and Chen (2007b) had validated the coupled multi-zone-CFD program by using experimental data. Results obtained with the coupled program had a good agreement with experimental data taken with non-uniform distributions of contaminant concentrations, air momentum effects and temperature. The coupled multi-zone-CFD simulation computed the entire flow in less time as compared to CFD alone. This will also give the better result for an improper mixed domain, when the assumptions of uniform flow fails. The coupled program assessed the airflow rates more accurately as compared to CONTAM simulations. Airflow rates were found to be lower with the coupled program than the CFD0 simulation due to the zero-equation turbulence model used. They had suggested that the standard k- $\varepsilon$ model will improve results in fact will take more computing time. Calogine et al. (2010) hase used statistical method based on Bayesian inference. They had mainly focused on the $\mathrm{CO}_{2}$ contamination in different rooms and the results were then compared with CONTAM and COMIS results. They found that this method is simple, effective and gives promising results. The results are also in line with the other commercial software. The relative importance of displacement term has revealed with the simulation in the formulation of pollutant deviation.

Transient Systems (TRNSYS) is a simulation program that used with a modular structure. TRNSYS supports numerous energy allied systems to be deliberated collected within a particular simulation domain (Duffy et al., 2009). TRNSYS energy assessment tool has been proficient of simulating entire building together with building airflow and heat transfer. Dols et al. (2015) has assessed the application of an efficient simulation program (TRNSYS/CONTAM) for wholebuilding coupled thermal, contaminant transport and airflow. They described the development of new CONTAM abilities in support of TRNSYS. They found out that it is easy to predict the time dependent exfiltration and infiltration proportions from doors, their influence on energy loss and subsequent entire building cooling and heating loads with the coupled CONTAM and TRNSYS simulations.

Ansys is a program works on finite volume method and it is purely CFD software. It is widely used in various studies in different-different fields. It is also widely used in indoor air quality to estimate the temperature, concentration of various pollutants etc. inside a building (Tian et al., 2006; Lai and Ho, 2008; Lim and Lee, 2008; Zhou and Kim, 2011). Few other programmes were also used for the evaluation of IAQ i.e. Star CCM, Open Foam etc. and provide good results for the estimation of air quality.

\section{Discussion on Literature}

Table 1 shows the IAQ studies which were carried out using CFD. Most of the studies were conducted using commercial software purely based on CFD while some studies were carried out using coupled approach. There are certain issues which need more attention, to obtain greater flexibility, accuracy etc. There is no such turbulence model which can provide the best solution for all kind of indoor air problems. In some problems large eddy simulation (LES) gives better solution for unsteady simulations and in some problem, RANS provide better solution. The choice of turbulence model is important as for contaminant dispersion improved zero-equation turbulence model is more reliable and faster in comparison with LES and standard $\kappa-\varepsilon$ model (Liu et al., 2018). If we try to establish a relationship between accuracy and computation time, for high 
International Journal of Mathematical, Engineering and Management Sciences

Vol. 4, No. 5, 1154-1168, 2019

https://dx.doi.org/10.33889/IJMEMS.2019.4.5-091

accuracy there is a need for high computation time. As simple zone methods they take quite less computational time but their accuracy is also less. Whereas CFD models predict good solutions but they are time-consuming. The computational time in CFD alone is maximum while minimum in the case of multi-zone models and for the coupled model it lays in between CFD and multizone models. So, the coupled approach provides a good solution for less computational effort. Sometimes there is a need for comprehensive characterization of the airflow which leads to the solution. The principle of symmetry can be applied to reduce the domain of study to reduce computation time and effort. The identification of symmetry inbuilt space is quite difficult and it is also important to study that geometrical representation of the physical problem.

Table 1 Computational study on various type of built environment

\begin{tabular}{|c|c|c|c|c|c|c|c|c|}
\hline $\begin{array}{l}\text { S. } \\
\text { No. }\end{array}$ & Study & Building & $\begin{array}{c}\text { Room } \\
\text { conditions/ } \\
\text { dimensions }\end{array}$ & Solver used & $\begin{array}{c}\text { Inlet } \\
\text { conditions }\end{array}$ & $\begin{array}{c}\text { Turbulence } \\
\text { model }\end{array}$ & $\begin{array}{c}\text { Parameters } \\
\text { studied }\end{array}$ & Results \\
\hline 1. & $\begin{array}{l}\text { Abanto et } \\
\text { al. ( 2004) }\end{array}$ & $\begin{array}{l}\text { Computer } \\
\text { Room }\end{array}$ & $\begin{array}{l}M_{0} \text { without } \\
\text { occupants } \\
M_{1} \text { with } 3 \\
\text { occupants }\end{array}$ & FLUENT & $\begin{array}{c}\mathrm{V}=0.83 \\
\mathrm{~m} / \mathrm{s}\end{array}$ & RNG k- $\varepsilon$ & $\begin{array}{l}\text { MAA, MRT, } \\
\text { PMV and } \\
\text { PPD }\end{array}$ & $\begin{array}{l}\text { Maximum } \mathrm{RH} \\
\text { in room is } 46 \% \text {. } \\
\text { - The maximum } \\
\text { temperature is } \\
354 \mathrm{~K} \text { at the } \\
\text { hottest surface } \\
\text { of computer. }\end{array}$ \\
\hline 2. & $\begin{array}{l}\text { Tian et al. } \\
\text { (2006) }\end{array}$ & Room & & FLUENT & $\begin{array}{c}\mathrm{V}=0.235 \\
\mathrm{~m} / \mathrm{s}\end{array}$ & $\begin{array}{c}\text { Standard k- } \\
\varepsilon \\
\text { RNG and } \\
\text { RNG based } \\
\text { LES }\end{array}$ & $\begin{array}{l}\text { Time mean } \\
\text { velocity field }\end{array}$ & $\begin{array}{l}\text { RNG based } \\
\text { LES model has } \\
\text { provided good } \\
\text { agreement with } \\
\text { measurement } \\
\text { along with more } \\
\text { realistic particle } \\
\text { dispersion. }\end{array}$ \\
\hline 3. & $\begin{array}{l}\text { Wang and } \\
\text { Emmerich } \\
\text { (2010) }\end{array}$ & $\begin{array}{l}\text { Portable } \\
\text { generator } \\
\text { operated } \\
\text { outdoors }\end{array}$ & $\begin{array}{l}\text { Direction of } \\
\text { generator } \\
\text { exhaust, } \\
\text { Placement, } \\
\text { open window } \\
\text { size }\end{array}$ & CONTAM & $\begin{array}{c}\mathrm{V}=1,5 \\
\text { and } 10 \mathrm{~m} / \mathrm{s}\end{array}$ & - & $\mathrm{CO}$ & $\begin{array}{l}\text { - Generator } \\
\text { placement in } \\
\text { airflow } \\
\text { recirculation } \\
\text { zone cause } \\
\text { major CO entry } \\
\text { (house). } \\
\text { - Perpendicular } \\
\text { wind to open } \\
\text { window causes } \\
\text { CO entry in the } \\
\text { house. }\end{array}$ \\
\hline 4. & $\begin{array}{l}\text { Sugahara } \\
\text { et al. } \\
(2017)\end{array}$ & $\begin{array}{l}\text { Open-type } \\
\text { wind } \\
\text { tunnel }\end{array}$ & & CFD & $\begin{array}{l}\text { Opening } \\
\text { ratio to } \\
\text { wall }=0 \text { or } \\
25 \%, \mathrm{~V}=1 \\
\text { or } 5 \mathrm{~m} / \mathrm{s}\end{array}$ & $\begin{array}{l}\text { Standard k- } \\
\varepsilon \text { model } \\
\text { (SIMPLE) }\end{array}$ & - & $\begin{array}{l}\text { Airflow field } \\
\text { became more } \\
\text { stagnant with } \\
\text { the distribution } \\
\text { of air } \\
\text { conditioning at } \\
\text { high density } \\
\text { region }\end{array}$ \\
\hline 5. & $\begin{array}{l}\text { Ding and } \\
\text { Lei } \\
(2013)\end{array}$ & $\begin{array}{l}\text { Room with } \\
\text { a partition }\end{array}$ & $\begin{array}{l}\text { Dimensions } \\
x=0.914 \mathrm{~m}, \\
y=0.305 \mathrm{~m}, \\
\mathrm{z}=0.457 \mathrm{~m}\end{array}$ & LBM & $\begin{array}{c}\mathrm{V}=0.235 \\
\mathrm{~m} / \mathrm{s}\end{array}$ & $\begin{array}{c}k-\varepsilon \\
\text { turbulence } \\
\text { model }\end{array}$ & $\begin{array}{l}\text { Particle } \\
\text { dispersion \& } \\
\text { Airflow } \\
\text { study }\end{array}$ & $\begin{array}{l}\text { LBM has ability } \\
\text { to capture the } \\
\text { turbulent } \\
\text { airflow } \\
\text { characteristics. } \\
\text { Results were in } \\
\text { better } \\
\text { agreement with } \\
\text { experimental } \\
\text { data. }\end{array}$ \\
\hline
\end{tabular}


International Journal of Mathematical, Engineering and Management Sciences

Vol. 4, No. 5, 1154-1168, 2019

https://dx.doi.org/10.33889/IJMEMS.2019.4.5-091

Table 1 continued ...

\begin{tabular}{|c|c|c|c|c|c|c|c|c|}
\hline 6. & $\begin{array}{l}\text { Sajjadi et } \\
\text { al. ( 2016) }\end{array}$ & $\begin{array}{l}\text { Scaled } \\
\text { room } \\
\text { model } \\
\text { (Partitioned } \\
\text { in height) }\end{array}$ & $\begin{array}{l}\text { Dimensions } \\
0.914 \times 0.305 \\
\times 0.457 \mathrm{~m} \text {, } \\
\text { Inlet \& outlet } \\
\text { are } \\
0.101 \times 0.101 \mathrm{~m}\end{array}$ & $\begin{array}{l}\text { LES, RANS } \\
\text { \& hybrid }\end{array}$ & $\begin{array}{c}\mathrm{V}=0.23 \\
\mathrm{~m} / \mathrm{s}\end{array}$ & $\begin{array}{c}k-\varepsilon \\
\text { turbulence }\end{array}$ & $\begin{array}{l}\text { Indoor } \\
\text { airflows }\end{array}$ & $\begin{array}{l}\text { The } \\
\text { computational } \\
\text { cost is low for } \\
\text { this model and } \\
\text { hybrid model is } \\
\text { effective in } \\
\text { prediction of } \\
\text { fluctuation in } \\
\text { velocity with } \\
\text { good accuracy. }\end{array}$ \\
\hline 7. & $\begin{array}{l}\text { Khan et } \\
\text { al. (2015) }\end{array}$ & $\begin{array}{l}\text { Four-bed } \\
\text { hospital } \\
\text { room }\end{array}$ & $\begin{array}{l}\mathrm{H}=2.26, \mathrm{~W} \\
=3.36 \\
\mathrm{~L}=4.20 \mathrm{~m} \\
\text { Inlet height }= \\
0.23 \mathrm{~m} \\
\text { Inlet width= } \\
0.48 \mathrm{~m}\end{array}$ & $\begin{array}{c}\text { LB method } \\
\text { based 3D } \\
\text { CFD } \\
\text { technique }\end{array}$ & $\begin{array}{c}\mathrm{V}=0.48 \\
\mathrm{~m} / \mathrm{s}\end{array}$ & - & $\begin{array}{l}\text { Time } \\
\text { evolution of } \\
\text { the turbulent } \\
\text { airflow \& } \\
\text { temperature } \\
\text { in tested } \\
\text { domain }\end{array}$ & $\begin{array}{l}\text { LBM has } \\
\text { significantly } \\
\text { having faster } \\
\text { computation } \\
\text { speed }\end{array}$ \\
\hline 8. & $\begin{array}{l}\text { Mu et al. } \\
(2015)\end{array}$ & Building & $\begin{array}{l}\mathrm{L}=1.0 \times 10^{-2} \\
\mathrm{~m} \\
\mathrm{H}=1.1 \times 10^{-} \\
{ }^{3} \mathrm{~m}\end{array}$ & LBM & & & $\begin{array}{ll}\text { Emission } & \\
\text { process } & \text { of } \\
\text { VOCs } & \text { in } \\
\text { chamber } & \end{array}$ & $\begin{array}{l}\text { VOCs in } \\
\text { building } \\
\text { material pores } \\
\text { are estimated } \\
\text { with the } \\
\text { proposed model }\end{array}$ \\
\hline 9. & $\begin{array}{l}\text { Wang and } \\
\text { Chen } \\
\text { (2008) }\end{array}$ & $\begin{array}{l}\text { 3story } \\
\text { natural } \\
\text { ventilated } \\
\text { building } \\
\text { with an } \\
\text { atrium }\end{array}$ & $\begin{array}{l}\text { Z 1-8: } 12 \times \\
6 \times 2.7 \mathrm{~m} \\
\text { Z } 9-12: 6 \times 9 \\
\times 2.7 \\
\text { Z13-14: } 6 \times 5 \\
\times 2.7 \\
\text { Atrium: } \\
48 \times 11 \times 10.8\end{array}$ & $\begin{array}{l}\text { Coupled } \\
\text { CFD - } \\
\text { multizone }\end{array}$ & & & $\begin{array}{l}\text { Airflow and } \\
\text { contaminant } \\
\text { dispersion }\end{array}$ & $\begin{array}{l}\text { Coupled model } \\
\text { take less } \\
\text { computational } \\
\text { time and } \\
\text { estimate } \\
\text { contaminant } \\
\text { distribution. }\end{array}$ \\
\hline 10. & $\begin{array}{l}\text { Jurelionis } \\
\text { and } \\
\text { Seduikyte } \\
(2008)\end{array}$ & $\begin{array}{l}\text { School } \\
\text { building }\end{array}$ & & $\begin{array}{c}\text { Measurement } \\
\text { and } \\
\text { survey, } \\
\text { CFD }\end{array}$ & & $\begin{array}{c}\quad k-\varepsilon \\
\text { turbulence }\end{array}$ & $\begin{array}{l}\text { Air quality, } \\
\text { temperature, } \\
\mathrm{RH} \text {, and air } \\
\text { velocity }\end{array}$ & $\begin{array}{l}\text { Temperature } \\
\text { was found most } \\
\text { critical } \\
\text { parameter. } \\
\text { Improper } \\
\text { ventilation can } \\
\text { cause more } \mathrm{CO}_{2}\end{array}$ \\
\hline 11. & $\begin{array}{l}\text { Song and } \\
\text { Meng } \\
(2015)\end{array}$ & $\begin{array}{l}\text { School } \\
\text { buildings }\end{array}$ & $\begin{array}{l}\text { Classroom: } \\
11 \times 9 \times 4 \\
\text { Windows: } 0.15 \\
\times 0.12 \\
\text { Doors: } \\
0.20 \times 0.14 \mathrm{~m}\end{array}$ & Fluent & & $\begin{array}{l}k-\varepsilon \\
\text { turbulence }\end{array}$ & $\begin{array}{l}\text { Air quality } \\
\text { and thermal } \\
\text { comfort }\end{array}$ & $\begin{array}{l}\text { Good } \\
\text { agreement } \\
\text { between the } \\
\text { investigation } \\
\text { and } \\
\text { Simulation. } \\
\text { Good } \\
\text { ventilation can } \\
\text { provide more } \\
\text { comfort to } \\
\text { students }\end{array}$ \\
\hline 12. & $\begin{array}{l}\text { Barbosa } \\
\text { and Brum } \\
(2018)\end{array}$ & $\begin{array}{l}\text { Hospital } \\
\text { and } \\
\text { laboratory } \\
\text { buildings }\end{array}$ & $\begin{array}{c}\text { Test domain: } \\
8 \times 8 \times 8 \mathrm{ft} \\
\text { Inlet and } \\
\text { Outlet: } 2.44 \\
\times 2.44 \times 2.44 \\
\text { m }\end{array}$ & $\begin{array}{c}\text { CFD-0 } \\
\text { CONTAM }\end{array}$ & $\mathrm{Re}=2600$ & $\begin{array}{l}k-\varepsilon \\
\text { turbulence }\end{array}$ & $\begin{array}{c}\text { Airborne } \\
\text { contaminant } \\
\text { transport }\end{array}$ & $\begin{array}{l}\text { CFD-0 } \\
\text { provided } \\
\text { acceptable } \\
\text { results for } \\
\text { contaminant } \\
\text { transport in } \\
\text { laboratory and } \\
\text { hospital } \\
\text { application. }\end{array}$ \\
\hline 13. & $\begin{array}{l}\text { Calogine } \\
\text { et al. } \\
\text { (2010) }\end{array}$ & Rooms & & $\begin{array}{l}\text { COMIS \& } \\
\text { CONTAM }\end{array}$ & & & $\mathrm{CO}_{2}$ & $\begin{array}{l}\text { Thermal } \\
\text { equations } \\
\text { affected the } \\
\text { airflow }\end{array}$ \\
\hline
\end{tabular}


International Journal of Mathematical, Engineering and Management Sciences

Vol. 4, No. 5, 1154-1168, 2019

https://dx.doi.org/10.33889/IJMEMS.2019.4.5-091

Table 1 continued ...

\begin{tabular}{|c|c|c|c|c|c|c|c|c|}
\hline 14. & $\begin{array}{l}\text { Zhou and } \\
\text { Kim } \\
(2011)\end{array}$ & $\begin{array}{l}\text { Kitchen } \\
\text { and living } \\
\text { room }\end{array}$ & $\begin{array}{l}5.05 \times 3.23 \times \\
2.3\end{array}$ & FLUENT & $\begin{array}{c}\text { air flow } \\
\text { rate }= \\
1.08 \mathrm{~m}^{3} / \mathrm{s}\end{array}$ & $\begin{array}{l}\text { standard k- } \\
\varepsilon \\
\text { turbulence } \\
\text { model }\end{array}$ & $\begin{array}{l}\text { Temperature } \\
\text { and } \\
\mathrm{CO}_{2} \\
\text { concentration }\end{array}$ & $\begin{array}{l}\text { Both the } \\
\text { parameters are } \\
\text { influenced by } \\
\text { the extraction } \\
\text { rate (flow) of } \\
\text { range hood }\end{array}$ \\
\hline 15. & $\begin{array}{l}\text { Chiang et } \\
\text { al. }(2000)\end{array}$ & Kitchen & & $\begin{array}{l}\text { Finite } \\
\text { volume } \\
\text { method }\end{array}$ & $\begin{array}{l}\mathrm{T}=26^{\circ} \mathrm{C} \\
\mathrm{q}=5.9 \times \\
10^{5} \\
\left(\mathrm{~W} / \mathrm{m}^{2}\right)\end{array}$ & & $\begin{array}{l}\text { flow fields, } \\
\text { temperature } \\
\text { fields and } \\
\text { CO } \\
\text { distributions }\end{array}$ & $\begin{array}{l}\text { Range hood } \\
\text { effectively } \\
\text { decreases the } \\
\text { air contaminant. } \\
\text { Air } \\
\text { contaminants } \\
\text { are higher at the } \\
\text { location of the } \\
\text { gas. }\end{array}$ \\
\hline 16. & $\begin{array}{l}\text { Gao et al. } \\
(2015)\end{array}$ & Kitchen & $\begin{array}{l}3.5 \times 1.8 \times 2.4 \\
(\mathrm{~m})\end{array}$ & $\begin{array}{c}\text { Euler-Euler } \\
\text { numerical } \\
\text { frame }\end{array}$ & & $\begin{array}{l}\text { standard k- } \\
\varepsilon \\
\text { turbulence } \\
\text { model }\end{array}$ & $\begin{array}{l}\text { Spatial } \\
\text { disperse-on, } \\
\text { Dynamic } \\
\text { emission } \\
\text { rate, } \\
\text { individual } \\
\text { expo-sure to } \\
\text { PAH }\end{array}$ & $\begin{array}{l}\text {-PPAH } \\
\text { emission rate } \\
\text { and applied } \\
\text { cooking oil } \\
\text { temperature had } \\
\text { close and } \\
\text { complicated } \\
\text { relationship } \\
\text {-Higher } \\
\text { emission } \\
\text { generally found } \\
\text { earlier than } \\
\text { peak } \\
\text { temperature } \\
\text { time }\end{array}$ \\
\hline 17. & $\begin{array}{l}\text { Lai and } \\
\text { Ho (2008) }\end{array}$ & Kitchen & $\begin{array}{l}4.2 \times 2.6 \times \\
4: 6(\mathrm{~m})\end{array}$ & $\begin{array}{c}\text { FLUENT } \\
6.1\end{array}$ & & $\begin{array}{l}\mathrm{k}-\varepsilon \\
\text { turbulence } \\
\text { model }\end{array}$ & $\mathrm{PM}_{2.5}$ & $\begin{array}{l}\text { Two locations } \\
\text { were selected } \\
\text { and result } \\
\text { shows that there } \\
\text { is significant } \\
\text { difference in } \\
\text { time lag and } \\
\text { concentration. }\end{array}$ \\
\hline
\end{tabular}

\section{Conclusions}

The study of the indoor environment is quite important as humans spent their maximum time indoors, even in the case of children it becomes more important as they are more prone to infection and stay more time indoors. The prediction of an indoor environment with the help of computational techniques is a good option and it decreases dependency on experiments. The advancement in computation leads to analyse the things in a better way but it requires more computational effort. However, the integration of CFD with BS (Building simulation) or other techniques is a better way of taking advantage of the strength of other models for study. The coupling of various other techniques i.e. GIS (Geographical information system) contributes in analysis and design of more complex IAQ problems efficiently. 
International Journal of Mathematical, Engineering and Management Sciences

Vol. 4, No. 5, 1154-1168, 2019

https://dx.doi.org/10.33889/IJMEMS.2019.4.5-091

\section{Conflict of Interest}

The authors confirm that this article contents have no conflict of interest.

\section{Acknowledgement}

Authors wish to acknowledge the National Institute of Technology Hamirpur for providing all necessary facility to conduct research work.

\section{References}

Abanto, J., Barrero, D., Reggio, M., \& Ozell, B. (2004). Airflow modelling in a computer room. Building and Environment, 39(12), 1393-1402.

Banerjee, A., Rai, A., \& Mohanty, B. (2017). Simulation of combustion space heat transfer of glass melting furnace. Heat Transfer-Asian Research, 46(6), 569-584.

Barbosa, B.P.P., \& Brum, N.D.C.L. (2018). Validation and assessment of the CFD-0 module of CONTAM software for airborne contaminant transport simulation in laboratory and hospital applications. Building and Environment, 142, 139-152.

Bartak, M., Beausoleil-Morrison, I., Clarke, J.A., Denev, J., Drkal, F., Lain, M., \& Stankov, P. (2002). Integrating CFD and building simulation. Building and Environment, 37(8-9), 865-871.

Calogine, D., Boyer, H., Ndoumbe, S., Rivière, C., \& Miranville, F. (2010). Identification of parameters in building concentration dispersion model. Indoor and Built Environment, 19(2), 250-266.

Chen, S., \& Doolen, G.D. (1998). Lattice Boltzmann method for fluid flows. Annual Review of Fluid Mechanics, 30(1), 329-364.

Chiang, C.M., Lai, C.M., Chou, P.C., \& Li, Y.Y. (2000). The influence of an architectural design alternative (transoms) on indoor air environment in conventional kitchens in Taiwan. Building and Environment, 35(7), 579-585.

Clarke, J.A. (2001). Energy simulation in building design. $2^{\text {nd }}$ Ed. Butterworth Heinemann

Clarke, J.A., \& Hensen, J.L.M. (2015). Integrated building performance simulation: Progress, prospects and requirements. Building and Environment, 91, 294-306.

Ding, L., \& Lai, A.C.K. (2013). An efficient lattice Boltzmann model for indoor airflow and particle transport. Journal of Aerosol Science, 63, 10-24.

Dols, W.S., Emmerich, S.J., \& Polidoro, B.J. (2016, August). Coupling the multizone airflow and contaminant transport software CONTAM with Energy Plus using co-simulation. In Building Simulation, (9(4), pp. 469-479). Tsinghua University Press.

Dols, W.S., Wang, L., Emmerich, S.J., \& Polidoro, B.J. (2015). Development and application of an updated whole-building coupled thermal, airflow and contaminant transport simulation program (TRNSYS/CONTAM). Journal of Building Performance Simulation, 8(5), 326-337.

Duffy, M.J., Hiller, M., Bradley, D.E., Keilholz, W., \& Thornton, J.W. (2009, July). TRNSYS-features and functionalitity for building simulation 2009 conference. In $11^{\text {th }}$ International IBPSA ConferenceBuilding Simulation, (pp. 1950-1954).

Fletcher, C.A.J., Mayer, I.F., Eghlimi, A., \& Wee, K.H.A. (2001). CFD as a building services engineering tool. International Journal on Architectural Science, 2(3), 67-82. 
International Journal of Mathematical, Engineering and Management Sciences

Vol. 4, No. 5, 1154-1168, 2019

https://dx.doi.org/10.33889/IJMEMS.2019.4.5-091

Gan, G. (1995). Numerical investigation of local thermal discomfort in offices with displacement ventilation. Energy and Buildings, 23(2), 73-81.

Gao, J., Jian, Y., Cao, C., Chen, L., \& Zhang, X. (2015). Indoor emission, dispersion and exposure of total particle-bound polycyclic aromatic hydrocarbons during cooking. Atmospheric Environment, 120, 191199.

Hong, T., Chou, S.K., \& Bong, T.Y. (2000). Building simulation: an overview of developments and information sources. Building and Environment, 35(4), 347-361.

Hong, T., Lee, M., \& Kim, J. (2017). Analysis of energy consumption and indoor temperature distributions in educational facility based on CFD-BES model. Energy Procedia, 105, 3705-3710.

Jafari, S., Salmanzadeh, M., Rahnama, M., \& Ahmadi, G. (2010). Investigation of particle dispersion and deposition in a channel with a square cylinder obstruction using the lattice Boltzmann method. Journal of Aerosol Science, 41(2), 198-206.

Jurelionis, A., \& Seduikyte, L. (2008, May). Indoor environmental conditions in Lithuanian schools. In 7th International Conference on Environmental Engineering, Vienna, Austria.

Khan, M.A.I., Delbosc, N., Noakes, C.J., \& Summers, J. (2015, August). Real-time flow simulation of indoor environments using lattice Boltzmann method. In Building Simulation, 8(4), pp. 405-414. Tsinghua University Press.

Kumar, R., \& Kumar, A. (2017). Computational fluid dynamics based study for analyzing heat transfer and friction factor in semi-circular rib-roughened equilateral triangular duct. International Journal of Numerical Methods for Heat \& Fluid Flow, 27(4), 941-957.

Kumar, R., Kumar, A., and Goel, V. (2019), Performance improvement and development of correlation for friction factor and heat transfer using computational fluid dynamics for ribbed triangular duct solar air heater. Renewable Energy, 131, 788-99.

Lai, A.C.K., \& Ho, Y.W. (2008). Spatial concentration variation of cooking-emitted particles in a residential kitchen. Building and Environment, 43(5), 871-876.

Lim, K., \& Lee, C. (2008). A numerical study on the characteristics of flow field, temperature and concentration distribution according to changing the shape of separation plate of kitchen hood system. Energy and Buildings, 40(2), 175-184.

Limb, M.J. (1997). Ventilation and acoustics: an annotated bibliography. Air Infiltration and Ventilation Centre, Great Britain <https://www.aivc.org >

Liu, J., Heidarinejad, M., Pitchurov, G., Zhang, L., \& Srebric, J. (2018). An extensive comparison of modified zero-equation, standard k- $\varepsilon$, and LES models in predicting urban airflow. Sustainable Cities and Society, 40, 28-43.

Magnussen, B.F., \& Hjertager, B.H. (1977, January). On mathematical modeling of turbulent combustion with special emphasis on soot formation and combustion. In Symposium (International) on Combustion, 16(1), pp. 719-729, Elsevier.

Mu, Y.T., Chen, L., He, Y.L., \& Tao, W.Q. (2015). Coupling finite volume and lattice Boltzmann methods for pore scale investigation on volatile organic compounds emission process. Building and Environment, 92, 236-245.

Nautiyal, H., Kumar, V., \& Thakur, A. (2010). CFD analysis on pumps working as turbines. Hydro Nepal: Journal of Water, Energy and Environment, 6, 35-37.

Negrao, C.O. (1995). Conflation of computational fluid dynamics and building thermal simulation, (Doctoral dissertation, University of Strathclyde).

Nielsen, P.V. (1974). Flow in air-conditioned rooms. Ph. D Thesis, Technical University of Denmark. 
International Journal of Mathematical, Engineering and Management Sciences

Vol. 4, No. 5, 1154-1168, 2019

https://dx.doi.org/10.33889/IJMEMS.2019.4.5-091

NIST (2005), NISTIR 7251, CONTAM 2.4 User guide and program, National Institute of Standards and Technology, Gaithersburg.

Qian, Y.H., d'Humières, D., \& Lallemand, P. (1992). Lattice BGK models for Navier-Stokes equation. EPL (Europhysics Letters), 17(6), 479.

Ruth, M., Maggio, J., Whelan, K., DeYoung, M., May, J., Peterson, A., \& Paterson, K. (2013). Kitchen 2.0: Design guidance for healthier cooking environments. International Journal for Service Learning in Engineering, Humanitarian Engineering and Social Entrepreneurship, Special Edition, 151-169.

Sajjadi, H., Salmanzadeh, M., Ahmadi, G., \& Jafari, S. (2016). Simulations of indoor airflow and particle dispersion and deposition by the lattice Boltzmann method using LES and RANS approaches. Building and Environment, 102, 1-12.

Shah, S., \& Dufva, K. (2017). CFD modeling of airflow in a kitchen environment: towards improving energy efficiency in buildings. South-Eastern Finland University of Applied Sciences Mikkeli.

Song, J., \& Meng, X. (2015). The improvement of ventilation design in school buildings using CFD simulation. Procedia Engineering, 121, 1475-1481.

Srebric, J., Yuan, J., \& Novoselac, A. (2008). On-site experimental validation of a coupled multizone and CFD model for building contaminant transport simulations. Ashrae Transactions, 114(1), 273-281.

Stratford, K., \& Pagonabarraga, I. (2008). Parallel simulation of particle suspensions with the lattice Boltzmann method. Computers \& Mathematics with Applications, 55(7), 1585-1593.

Succi, S. (2001). The lattice Boltzmann equation: for fluid dynamics and beyond. Oxford University Press.

Sugahara, A., Kotani, H., Momoi, Y., Yamanaka, T., Sagara, K., \& Fujiwara, R. (2017). PIV measurement and CFD analysis of airflow around building roof with various building installations. International Journal of Ventilation, 16(3), 163-173.

Teodosiu, R., Ilie, V., \& Teodosiu, C. (2014), Computational fluid dynamics prediction of indoor air quality. In. Proc. of the Second Intl. Conf. on Advances in Civil, Structural and Environmental Engineering-ACSEE-2014, p. 26-30.

Tian, Z.F., Tu, J.Y., Yeoh, G.H., \& Yuen, R.K.K. (2006). On the numerical study of contaminant particle concentration in indoor airflow. Building and Environment, 41(11), 1504-1514.

United Nations (2016), Department of economic and social affairs, population division. The World's Cities in 2016-Data Booklet, (ST/ESA/ SER.A/392).

Wang, L., \& Chen, Q. (2007a). Theoretical and numerical studies of coupling multizone and CFD models for building air distribution simulations. Indoor Air, 17(5), 348-361.

Wang, L., \& Chen, Q. (2007b). Validation of a coupled multizone-CFD program for building airflow and contaminant transport simulations. HVAC \& R Research, 13(2), 267-281.

Wang, L., \& Chen, Q. (2008). Applications of a coupled multizone-CFD model to calculate airflow and contaminant dispersion in built environments for emergency management. HVAC \& $R$ Research, 14(6), 925-939.

Wang, L.L., \& Emmerich, S.J. (2010, March). Modeling the effects of outdoor gasoline powered generator use on indoor carbon monoxide exposures. In Building Simulation, 3(1), pp. 39-50. Tsinghua Press.

Wang, Y., Kuckelkorn, J., Zhao, F.Y., Spliethoff, H., \& Lang, W. (2017). A state of art of review on interactions between energy performance and indoor environment quality in passive house buildings. Renewable and Sustainable Energy Reviews, 72, 1303-1319.

Zhai, Z.J., \& Chen, Q.Y. (2005). Performance of coupled building energy and CFD simulations. Energy and Buildings, 37(4), 333-344. 
International Journal of Mathematical, Engineering and Management Sciences

Vol. 4, No. 5, 1154-1168, 2019

https://dx.doi.org/10.33889/IJMEMS.2019.4.5-091

Zhou, J., \& Kim, C.N. (2011). Numerical investigation of indoor CO2 concentration distribution in an apartment. Indoor and Built Environment, 20(1), 91-100.

Zhuang, R., Li, X., \& Tu, J. (2014, June). CFD study of the effects of furniture layout on indoor air quality under typical office ventilation schemes. In Building Simulation, 7(3), pp. 263-275. Springer Berlin Heidelberg. 